\title{
Carbon dioxide quantified by the infrared in evaluation of respiratory activity of wheat seeds ${ }^{1}$
}

\author{
João Alexandre Lopes Dranski ${ }^{2 *}$, Marlene de Matos Malavasi ${ }^{2}$, Ubirajara Contro Malavasi ${ }^{2}$, \\ Ivan Schuster ${ }^{3}$, Norma Lazaretti ${ }^{4}$ \\ $10.1590 / 0034-737 X 201764050008$
}

\begin{abstract}
The objective of this study was to develop and validate the methodology of carbon dioxide concentration in the evaluation of vigor of Triticum aestivum $\mathrm{L}$. seeds based on infrared spectroscopy. The proposed method quantifies $\mathrm{CO}_{2}$ content using a drag system and exhaustion to the gas released by the seeds. Samples of 50 seeds of six lots of cultivar $\mathrm{CD} 123$ were incubated at temperatures of 15,25 and $40^{\circ} \mathrm{C}$. The $\mathrm{CO}_{2}$ content released after 1, 3, 6, 9, 12 and $24 \mathrm{~h}$ of incubation were quantified. Additionally, the percentage of normal seedlings emerged in the field were evaluated. The simple correlation coefficients were evaluated among tests. After determining the reading conditions, the precision and accuracy of the proposed method were evaluated, using 15 lots of seeds. For the evaluation of the respiratory activity in Triticum aestivum seeds, a sample of 25 seeds, incubated at $25^{\circ} \mathrm{C}$ for a minimum of $12 \mathrm{~h}$ is recommended since it allows to classify lots with different levels of vigor and predict the establishment of seedlings in the field, being the appropriate method for measuring $\mathrm{CO}_{2}$ as it externalizes precision between successive measurements and agreement with the reference method.
\end{abstract}

Key words: $\mathrm{CO}_{2}$; infrared spectroscopy; Triticum aestivum $\mathrm{L}$.; validation method.

\section{RESUMO}

\section{Dióxido de carbono quantificado pelo infravermelho na avaliação da atividade respiratória em sementes de trigo}

Objetivou-se desenvolver e validar a metodologia da concentração de dióxido de carbono na avaliação do vigor de sementes de Triticum aestivum L. com base na espectroscopia no infravermelho. O método proposto quantifica o conteúdo de $\mathrm{CO}_{2}$ através de um sistema de arraste e exaustão do gás liberado pelas sementes. Amostras de 50 sementes, de seis lotes da cultivar CD 123 foram incubadas sob temperaturas de 15,25 e $40^{\circ} \mathrm{C}$. Quantificou-se o conteúdo de $\mathrm{CO}_{2}$ liberado após 1, 3, 6, 9, 12 e $24 \mathrm{~h}$ de incubação. Paralelamente, avaliou-se a porcentagem de plântulas normais emergidas em campo. Foram calculados os coeficientes de correlação simples entre os testes. Após a determinação das condições de leitura, avaliou-se a precisão e exatidão utilizando 15 lotes de sementes. Para a avaliação da atividade respiratória em sementes de Triticum aestivum recomenda-se que amostras sejam incubadas a $25^{\circ} \mathrm{C}$ por um período mínimo de $12 \mathrm{~h}, \mathrm{o}$ que possibilita classificar lotes em diferentes níveis de vigor e predizer o estabelecimento de plântulas em campo, sendo o método adequado para a mensuração de $\mathrm{CO}_{2}$, pois externa precisão entre medidas sucessivas e concordância ao método de referência.

Palavras-chave: Triticum aestivum L.; $\mathrm{CO}_{2}$; espectroscopia no infravermelho; validação.

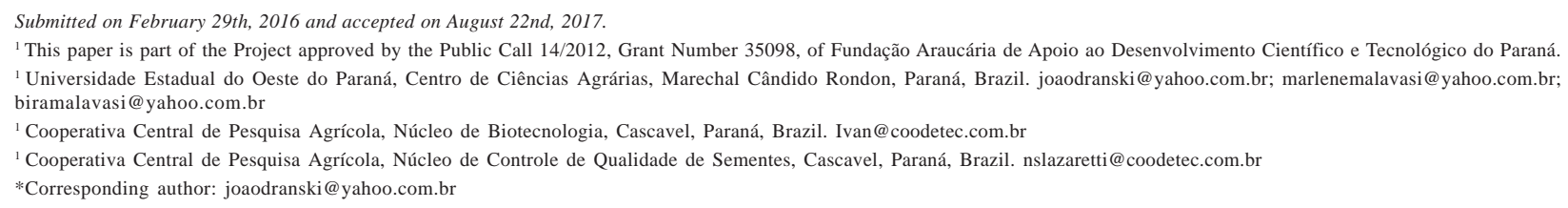




\section{INTRODUCTION}

Wheat (Triticum aestivum L.) is a cereal of great importance in the world for human and animal nutrition. It is considered a dominant crop in areas of subtropical and temperate climate; it has a significant impact on the world agricultural economy. In Brazil, whose domestic consumption is estimated at 12.25 million tons, a production of 7.89 million tons is projected for 2019, so the Brazilian production of this cereal is still lower than the supply demand (Mapa, 2016).

The investigation for self-sufficiency in production and higher productivity partly depends on the quality of the seeds used in the crop. Vigor tests have been used in tools used by the seed industry to eliminate low-quality seed lots for commercialization. Respiratory activity is one of the first biological manifestations of loss of vigor (Rosental et al., 2014) and its detection may help in the monitoring and control of the quality of seed production by the seed industries.

Respiratory activity is measured through the consumption of oxygen, calorimetry, and carbon dioxide $\left(\mathrm{CO}_{2}\right)$ content released by the respiratory process via titration, fluorescence, and gas chromatography (Mendes et al., 2009; Schabes \& Sigstad, 2011). However, these methods require time, skilled labor and present high operational costs, limiting their diffusion in seed analysis and laboratory routines.

Carbon dioxide can also be quantified by infrared spectroscopy (Dranski et al., 2013; Dantas et al., 2015). This technology enables the analysis of non-destructive samples and repeated measurements of a single seed or even a seed sample either in the dry state or with germination in progress in a short time, but little information on its use in evaluating seed vigor is available.

Although these studies already present indicatives of a methodology for the evaluation of the $\mathrm{CO}_{2}$ released by the seeds, the alternative method proposed by the present work suggests the modification of the collection and expression of the results obtained by a gas analyzer. Consequently, the indication of a certain test must be preceded by methodological validation procedures (Kataoka et al., 2011).

The evaluation of the $\mathrm{CO}_{2}$ concentration by the proposed infrared consists of exhausting the contents of the gas released by the seeds, kept in a closed system, up to the gas meter detection chamber. The meter chamber remains at constant $\mathrm{CO}_{2}$ flow and concentration, serving as the baseline, much like gas chromatography. When content dragging occurs, a peak similar to that of a chromatogram can be detected and constructed, whose area represents its content, therefore, capable of being compared.
Several factors may influence the result, making it necessary to define a methodology that allows the separation of seed lots more accurately, since the incubation temperature and the time necessary for the evaluation can affect the respiratory rates, in the case of seeds with high physiological potential.

The objective of this study was to develop and validate the methodology of carbon dioxide concentration in the evaluation of vigor of Triticum aestivum L. seeds.

\section{MATERIAL AND METHDOS}

\section{Development of the carbon dioxide concentration method}

\section{Seed sample and phisiological quality characterizaton}

Six basic seed lots of Triticum aestivum of cultivar CD 123 were used, granted by Cooperativa Central de Pesquisa Agrícola - COODETEC (Central Cooperative of Agricultural Research). The seeds were from the 2013 crop, with moisture content of $14.1 \pm 0.3 \%$, and $30.8 \pm 1.2 \mathrm{~g}$ of the average weight of one thousand seeds. The seeds were received with no treatment with pesticides. During the experiment, the seeds were stored in Kraft paper boxes and kept in a dry chamber adjusted to $20 \pm 2 \mathrm{oC}$, with a relative humidity of $40 \pm 3 \%$.

The following were determined: Germination - The germination test was conducted with four replicates of 100 seeds, using the germitest paper roll method, packed in a germinator at $20.0 \pm 2.0^{\circ} \mathrm{C}$, in a 12 -h photoperiod. The results were expressed as a percentage of normal seedlings obtained on the eighth day after sowing, as recommended by the Rules for Seed Analysis (Brasil, 2009). First Germination Count - The test was carried out simultaneously to the germination test by counting the percentage of normal seedlings obtained on the fourth day after sowing (Brasil, 2009). Seedling dry mass - It was obtained from the normal seedlings resulting from the germination test, removed after the second count, dried in an air circulation oven at $80{ }^{\circ} \mathrm{C}$ for $24 \mathrm{~h}$ and the results expressed in $\mathrm{mg}$ per seedling (ISTA, 1995). Potassium leaching - The test was conducted with four replicates of 50 seeds, packed in containers containing 75 $\mathrm{mL}$ of deionized water at $25^{\circ} \mathrm{C}$ for three hours. The readings were obtained with the aid of a flame photometer and the results expressed in $\mu \mathrm{mol}$ g- 1 of seeds (Favarato et al., 2011). Electrical conductivity - The test was conducted with four replicates of 50 seeds, packed in containers containing $75 \mathrm{~mL}$ of deionized water at $25 \mathrm{oC}$ for $18 \mathrm{~h}$ (Loeffler et al., 1988). Field emergence - The test was conducted with four blocks of 100 seeds that were sown in August 2013, in furroes with $5.0 \mathrm{~m}$ in length and $3.0 \mathrm{~cm}$ in depth, with furrows spaced by $30 \mathrm{~cm}$, under conditions of the field, without irrigation. The percentage of emerged 
normal seedlings was computed on day twenty-one after sowing (Nakagawa, 1994).

\section{Determination of carbono dioxide concentration}

Quantification of $\mathrm{CO}_{2}$ was performed by assessing the $\mathrm{CO}_{2}$ content released during respiration with the aid of an IRGA gas exchange meter (LI-COR 6400 XT). An injection system and a $\mathrm{CO}_{2}$-free air flow, coupled with the equipment, were fitted with an airflow compressor set in $140 \mathrm{~mL} \mathrm{~min}_{-1}$, which injects air into a $50 \mathrm{~mL}$-jar filled with soda lime properly sealed and with a rubber septum for injectables. Plastic hoses with a diameter of $3.0 \mathrm{~mm}$ and a length of $15 \mathrm{~cm}$ were used for connecting the system formed by the compressor, soda lime container, and sample jar, and disposable hypodermic needles (1.6 mm x $40 \mathrm{~mm}$ ) were coupled at the ends. A segment of plastic hose with the same characteristics described above was attached to the equipment, one end being fixed in the IRGA gas chamber and the other inserted in the sample bottle. Therefore, two needles were inserted into the sample flask at reading, and then the air flow system was run simultaneously with the equipment.

For sample preparation, four replicates of 50 seeds were used, accommodated in 50-mL glass containers, and then added with deionized water, whose volume allowed to reach a moisture content of $30 \%(\mathrm{~m} / \mathrm{m})$, according to Equation 1, then closed with a rubber septum for injectables and properly sealed. The containers were then incubated in BOD-type chambers at temperatures of 15 , 25 and $40 \mathrm{oC}$.

$\mathrm{Vol}(\mathrm{g})=\left[\left(\mathrm{MA}-\frac{\mathrm{MA}-\left[\mathrm{MA} * \frac{\mathrm{GU}}{100}\right]}{1-(0.01 * \mathrm{GUD})}\right)\right]$

Where: MA - sample mass (g); GU: moisture content (\%); GUD - moisture content to be reached (\%).

Readings for carbon dioxide concentration were performed at 1, 3, 6, 9, 12 and $24 \mathrm{~h}$ of incubation. Regarding achievement of the value of each repetition, the equipment was self-programmed to capture the $\mathrm{CO}_{2}$ concentration every $0.5 \mathrm{~s}$ until the complete exhaustion of the contents. The gas analyzer chamber was maintained at a constant concentration of $380 \mu \mathrm{mol}$ of $\mathrm{CO}_{2}$, with a flow of $500 \mu \mathrm{mol}$ $\mathrm{s}-1$. From the values of each repetition, the gas peaks were adjusted to a log-normal distribution and the peak area was obtained, according to Equation 2 proposed by Felinger (1998) and the results expressed in mmol of $\mathrm{CO}_{2}$ per gram of seeds.

$f(t)=\frac{A}{X} \operatorname{EXP}\left[-0.5\left(\frac{\operatorname{In}\left(t-t_{0}\right)}{\sigma}\right)^{2}\right]$

Where: $\mathrm{A}=$ peak area $(\mu \mathrm{mol} \mathrm{CO})$;

\section{Data analysis}

A completely randomized desing was used for the evaluation of the physiological quality. The emergence in the field used the randomized block design. In the $\mathrm{CO}_{2}$ concentration evaluation, a randomized block design was used in a factorial arrangement ( $6 \times 6$ ), comprising six lots and six incubation time periods. The incubation temperature factor was approached alone.

The data obtained were investigated as to the normality of residue distribution by the Shapiro-Wilk test, and the homogeneity of the variance by the Bartlet test. Subsequently, the data were submitted to analysis of variance. When there were statistically significant differences, the means between the lots were grouped by the Scott-Knott test at 5\% probability of error. For the period, the regression analysis was used. Then, the simple correlation coefficients between the carbon dioxide concentration and the results of the vigor and field performance tests were obtained at the level of $5 \%$ of probability of error by the $t$ test.

\section{Carbon dioxide concentration method validation}

Fifteen lots of basic seeds of Triticum aestivum cultivar CD 123, harvested in 2013, with a moisture content of $10.2 \pm 0.2 \%$ were used. The percentage of germination as described above was evaluated.

The concentration of $\mathrm{CO}_{2}$ was obtained in 20 replicates of 50 seeds that were placed in $50-\mathrm{mL}$ glass containers, then added with deionized water, whose volume allowed to reach the humidity of $30 \%$, according to Equation 1 . The containers were incubated in BOD type chambers at temperatures of $25^{\circ} \mathrm{C}$ for $12 \mathrm{~h}$. Expression of the results occurred as described previously. After obtaining the results, the Grubbs test was applied to the level of $95 \%$ of error probability for detection of extreme values.

For the validation of the developed method, the validation parameters of the precision and accuracy proposed by ISO 5725-2 (1994) were used. Precision Precision analysis was performed by repeatability analysis by comparing critical repeatability limit (CRL) with total amplitude $(\hat{\mathrm{A}})$ at the $1 \%$ error probability level and by analysis of variance. For this, ten samples were read on two different days for the same lot. For the comparison of the days of analysis by lot, the analysis of variance was used at the level of $5 \%$ of error probability. Accuracy - Accuracy analysis was performed by comparing methods using the gas chromatography results as the reference. For that purpose, 2-mL samples were extracted from four replicates per lot with the aid of a $2.5-\mathrm{mL}$ analytical syringe and then injected into a gas chromatograph equipped with a methanator, flame ionization detector, and hydrocarbon capillary column. 
Concentration of $\mathrm{CO}_{2}$ was quantified by comparing the areas of the chromatographic peaks of the samples and the analytical standard of $\mathrm{CO}_{2}$; the results were expressed in $\mathrm{mmol} \mathrm{CO}_{2} \mathrm{~g}^{-1}$. The simple correlation coefficient between the results obtained by infrared and gas chromatography (reference) was calculated, and the $t$ test was applied at a 5\% probability of error in the comparison of the methods.

\section{RESULTS AND DISCUSSION}

\section{Determination of carbon dioxide concentration}

The evaluation of the physiological quality indicated the occurrence of significant differences in the percentage of normal seedlings of the germination test (Table 1). Two groups were formed, where the one with the lowest viability resulted in a germination of $94 \%$ and the other lots with a mean of $98 \%$, with all lots showing a germination percentage greater than the minimum $(70 \%)$ recommended by Normative Instruction 45/2013 of the Ministry of Agriculture, Livestock and Supply, which deals with the establishment of identity and quality standards for the production and commercialization of Triticum aestivum seeds (Brasil, 2013).

The vigor assessment indicated that membrane integrity measured by potassium leaching tests and electrical conductivity (Table 1) were the most sensitive tests in the separation of lots with similar germination, due to the formation of three groups. Such groups covered lots 2 to lot 6 , suggesting that the highest velocity of restoring of cell membrane integrity during imbibition results in lower releasement of solutes to the outer media in higher vigor seeds (Marcos Filho, 2015). The loss in the integrity of biological membranes is an effect caused by the deterioration that occurs in advance to the loss of germination speed and seedling growth (Benamar et al., 2003) because these physiological effects evaluated by the test of the first germination count and dry mass of seedlings, respectively, only allowed the formation of two groups of the respective plots.
When the results of laboratory tests are compared with field performance (Table 1), it was observed that tests based on membrane integrity allowed to predict the field performance of wheat seeds, considering that the lots with the highest percentage of emergence in the field (lots 5 and 6) differed between exudate release rates, while the other tests did not present detection of sensitivity.

The loss of vigor is a result of physiological, biochemical, physical and ontogenetic changes that occur in advance of the loss of viability (Menezes et al., 2014), which corroborates with the results of the vigor tests for intermediate emergency rate lots (Lots 2, 3 and 4).

The concentration of $\mathrm{CO} 2$ released by wheat seeds was adjusted to the exponential model when incubation was carried out at temperatures of 15 and $25 \mathrm{oC}$ (Figure 1). For samples incubated at $40 \mathrm{oC}$, the data were adjusted to a sigmoidal model of three parameters, and after $18 \mathrm{~h}$, the point of maximum inflection of the curve was obtained, indicating that from this moment, the increase in $\mathrm{CO} 2$ concentration is minimum and stability begins, culminating in the threshold. This moment is indicative that even with the advancement in hydration, the respiratory activity becomes limited by decarboxylation and phosphorylative capacity (Weitbrecht et al., 2011).

The intense respiratory activity in the first hours of imbibition is necessary for the generation of the redox state (Rosental et al., 2014) and the energetic requirement is directed to the production of systems of removers of reactive forms of oxygen in seeds of lower physiological potential submitted to supra-optimal temperatures (Dantas et al., 2015).

According to Figure 1, the reduction in the concentration of $\mathrm{CO}_{2}$ released from wheat seeds is noticeable as a function of the reduction in temperature, and after $24 \mathrm{~h}$ of incubation at $15 \mathrm{oC}$, the reduction in the $\mathrm{CO}_{2}$ release is three times lower than that observed at 40 oC. Modulation in the enzymatic kinetics is directly proportional to the temperature at which seeds are found (Bandeira et al., 2013), besides reflecting the thermal

Table 1: Percentage of normal seedlings in germination test (NS), first germination count (FC), dry mass of seedlings (PDM), potassium leaching (KL), electrical conductivity (EC) and field emergence (FE) of six lots of Triticum aestivum CD 123 seeds

\begin{tabular}{|c|c|c|c|c|c|c|}
\hline \multirow{2}{*}{ Lot } & NS & FC & \multirow{2}{*}{$\frac{\text { PDM }}{\text { mg }^{-1}}$} & \multirow{2}{*}{$\frac{\mathrm{KL}}{\mu \mathrm{mol} \mathbf{g}^{-1}}$} & \multirow{2}{*}{$\frac{\mathrm{EC}}{-\mu \mathrm{S} \mathrm{cm} \mathrm{\textrm {g } ^ { - 1 }}}$} & \multirow{2}{*}{$\begin{array}{c}\mathbf{F E} \\
\%\end{array}$} \\
\hline & & & & & & \\
\hline 1 & $94.0 \mathrm{~b}$ & $91.0 \mathrm{~b}$ & $21.55 \mathrm{c}$ & $188.50 \mathrm{a}$ & $42.22 \mathrm{a}$ & $91.0 \mathrm{c}$ \\
\hline 2 & $97.0 \mathrm{a}$ & $93.5 b$ & $22.54 b$ & $182.96 a$ & $39.90 \mathrm{a}$ & $93.0 \mathrm{~b}$ \\
\hline 3 & $98.0 \mathrm{a}$ & $92.5 b$ & $22.52 b$ & $185.66 \mathrm{a}$ & $38.04 \mathrm{~b}$ & $94.5 b$ \\
\hline 4 & $97.0 \mathrm{a}$ & $94.5 \mathrm{a}$ & $23.64 \mathrm{a}$ & $171.07 \mathrm{~b}$ & $38.87 \mathrm{~b}$ & $93.5 b$ \\
\hline 5 & $97.0 \mathrm{a}$ & $96.0 \mathrm{a}$ & $23.67 \mathrm{a}$ & $156.64 b$ & $36.63 b$ & $98.5 \mathrm{a}$ \\
\hline 6 & $99.0 \mathrm{a}$ & $95.0 \mathrm{a}$ & $23.45 \mathrm{a}$ & $73.82 \mathrm{c}$ & $23.85 \mathrm{c}$ & $97.5 \mathrm{a}$ \\
\hline $\mathrm{CV}(\%)$ & 1.8 & 1.9 & 1.9 & 7.2 & 5.1 & 1.8 \\
\hline
\end{tabular}

Means followed by the same lowercase letter in the column do not differ statistically from each other at the level of 5\% of error probability by the Scott-Knott test.

Rev. Ceres, Viçosa, v. 64, n.5, p. 507-515, set/out, 2017 
requirements necessary for the occurrence of root production (Patanè \& Avola, 2013).

Therefore, the objective of temperature manipulation in the evaluation of respiratory activity is to expose the seeds to adverse conditions from that considered optimum, since the ability of seeds to germinate under a broad thermal limit is a manifestation of their vigor. Therefore, seeds that tolerate a greater thermal variation are the most vigorous and susceptible to segregation by respiratory activity.

It was possible to separate lots of wheat seeds at three vigor levels after $24 \mathrm{~h}$ of incubation at $15{ }^{\circ} \mathrm{C}$. The composition of groups occurred similarly to that observed after 12 and $24 \mathrm{~h}$ of incubation at $25^{\circ} \mathrm{C}$ (Table 2). The incubation at $40{ }^{\circ} \mathrm{C}$ allowed the separation of the lot with lower physiological potential, therefore, when the objective is seed vigor evaluation, the use of this temperature is not recommended since it was not possible to separate lots of higher physiological potentials from the intermediary vigor.

It is also stressed that the composition of the groups arranged after $24 \mathrm{~h}$ at $15^{\circ} \mathrm{C}$ and after $12 \mathrm{~h}$ of incubation at $25^{\circ} \mathrm{C}$, the similarity of the observed one to field emergence (Table 1), whose lots with the highest emergency rate released a $\mathrm{CO}_{2}$ 14\% lower than the lot with reduced physiological potential, as well as the average values obtained after $24 \mathrm{~h}$ of incubation at $15^{\circ} \mathrm{C}$ were similar to those obtained with a $12 \mathrm{~h}$ incubation at $25^{\circ} \mathrm{C}$, reducing by half the period of time necessary to separate the lots at different levels of vigor.

The simple correlation analysis between the values obtained from the $\mathrm{CO}_{2}$ concentration and the percentage of normal seedlings emerged in the field revealed the existence of a significant negative correlation $(\mathrm{p}<0.05)$ from $9 \mathrm{~h}$ of incubation, when incubated at $15^{\circ} \mathrm{C}$ (Table 2). For samples incubated at $25{ }^{\circ} \mathrm{C}$, correlation coefficients lower than -0.85 were obtained after three hours of incubation. These results indicate that field emergence was inversely proportional to the concentration of the released $\mathrm{CO}_{2}$. Therefore, seed lots that release less $\mathrm{CO}_{2}$ per unit of mass are the ones with the best performance in the field. For samples incubated at $40{ }^{\circ} \mathrm{C}$, no significant correlation was found.

The increase in $\mathrm{CO}_{2}$ content released as a function of loss of viability is linked to the structural changes in the biological membranes caused by lipid peroxidation, which influence the viscosity, permeability and cellular functions of the mitochondria (Shaban, 2013). Therefore, the passage from the dry state to the fluid of the cell membranes promotes the rapid diffusion and capillarity of the water in aged seeds, and the advance in the faster absorption of water causes the mitochondria present in dry seeds to resume its metabolic activity more quickly, resulting in a higher $\mathrm{CO}_{2}$ release in wheat seeds, as it can be illustrated by the correlation coefficient of $0.83(\mathrm{p}=0.0321)$ between the values obtained by the electrical conductivity test with the $\mathrm{CO}_{2}$ concentration released after $12 \mathrm{~h}$ of incubation at $25^{\circ} \mathrm{C}$.

Attention should be given to the fact that the germination speed and the seedling growth rate were inversely proportional to the content of $\mathrm{CO}_{2}$ released, considering that the simple correlation coefficients were 0.92 and -0.88 ( $p<0.05)$, respectively, which corroborates with those reported by Rosental et al. (2014), whose respiratory activity is indicative of vigor and its reduction directly affects the speed and growth rate of the seedlings.

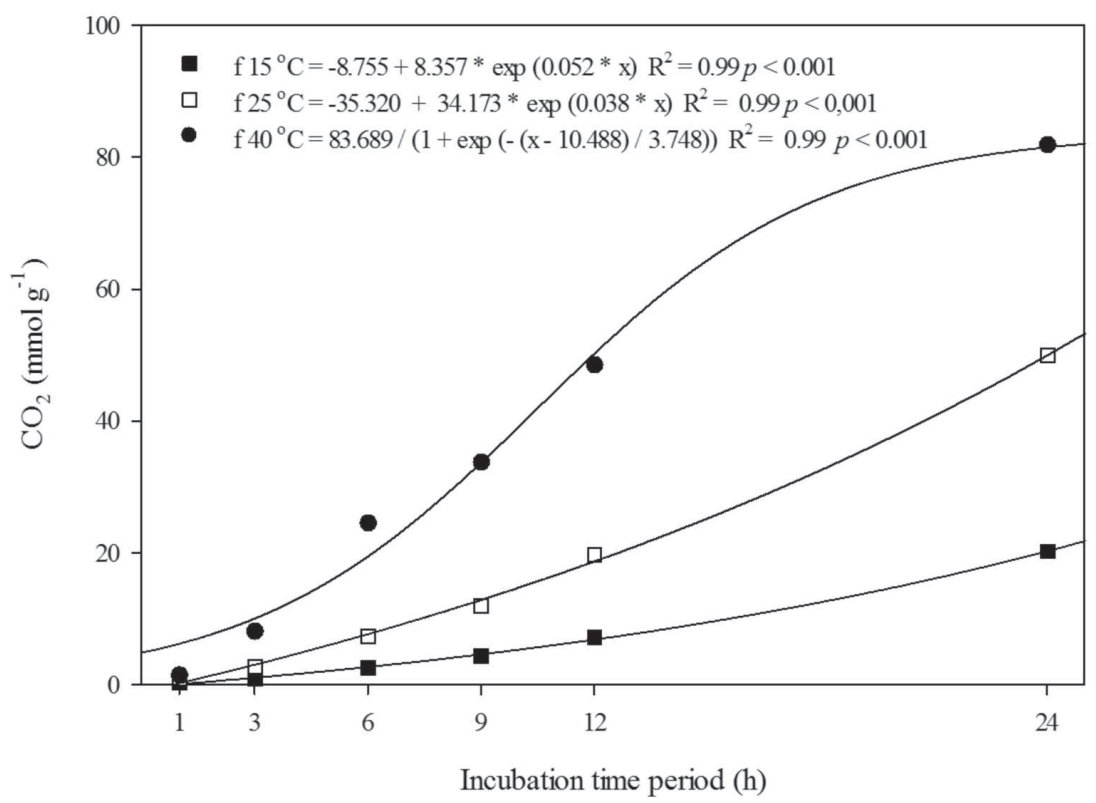

Figure 1: Concentration of $\mathrm{CO}_{2}$ released from Triticum aestevium $\mathrm{CD} 123$ seeds as a function of time and incubation temperature. 
The high coefficients of correlation between the concentration of $\mathrm{CO}_{2}$ obtained with the percentage of emerged seedlings suggest that the methodology was efficient in the prediction of the establishment of seedlings in the field, however, temperatures lower than or equal to $25{ }^{\circ} \mathrm{C}$ allow the greater separation of the lots, resulting in greater sensitivity in detecting differences in physiological potential in Triticum aestevium seeds not detected by viability tests, therefore, with the potential to classify lots according to their performance potential.

\section{Validation of the analitical method}

The test of Grubbs applied in twenty replicates for the fifteen lots did not detect the presence of extreme values (Figure 2a). This test verifies the existence of an atypical value at each end of the set (Chui et al., 2009). Extreme values can be considered as a natural variation in a set of data or even by errors of measurement, execution, and operation.
Evaluation of accuracy by comparing the critical limit of repeatability (CLR) indicated an acceptable repeatability for the 15 tested lots since results of individual total amplitude remained below the calculated critical limit at a significance level of $1 \%$ (Figure $2 \mathrm{~b}$ ). These results express the degree of agreement between the results of successive measurements of the same measurand (represented by seed lots) carried out under the same predetermined measurement conditions.

According to the analysis of variance, there was no evidence of significant differences in the obtention of the concentration of $\mathrm{CO}_{2}$ in different working days (Table 3), which indicates precision in the achievement of the results for the 15 lots of wheat seeds, since even with the changing in the shifts, the method allowed to obtain statistically identical results.

The results for the accuracy analysis showed agreement between the quantification by the infrared gas analyzer and that obtained by gas chromatography

Table 2: Concentration of $\mathrm{CO}_{2}$ released from Triticum aestevium $\mathrm{CD} 123$ seeds as a function of the lot and incubation time and its correlation ( $r$ ) with the percentage of the emergence of seedlings in the field

\begin{tabular}{|c|c|c|c|c|c|c|c|}
\hline \multirow{3}{*}{$\begin{array}{l}\text { Temperature } \\
\left({ }^{\circ} \mathrm{C}\right)\end{array}$} & \multirow{3}{*}{ Lot } & \multicolumn{6}{|c|}{ Incubation time period (h) } \\
\hline & & 1 & 3 & 6 & 9 & 12 & 24 \\
\hline & & \multicolumn{6}{|c|}{$\mathrm{mmol} \mathrm{g}^{-1}$} \\
\hline \multirow[t]{6}{*}{15} & 1 & $0.30 \mathrm{a}$ & $0.90 \mathrm{a}$ & $2.62 a$ & $4.74 \mathrm{a}$ & $7.33 a$ & $21.73 \mathrm{a}$ \\
\hline & 2 & $0.31 \mathrm{a}$ & $0.94 \mathrm{a}$ & $2.46 \mathrm{a}$ & $4.45 \mathrm{a}$ & $7.43 \mathrm{a}$ & $21.00 \mathrm{~b}$ \\
\hline & 3 & $0.34 \mathrm{a}$ & $0.86 \mathrm{a}$ & $2.51 \mathrm{a}$ & $4.19 \mathrm{a}$ & $7.18 \mathrm{a}$ & $20.67 b$ \\
\hline & 4 & $0.29 \mathrm{a}$ & $0.88 \mathrm{a}$ & $2.77 \mathrm{a}$ & $4.22 \mathrm{a}$ & $7.23 \mathrm{a}$ & $20.21 b$ \\
\hline & 5 & $0.28 \mathrm{a}$ & $0.94 \mathrm{a}$ & $2.85 \mathrm{a}$ & $4.10 \mathrm{a}$ & $6.79 b$ & $18.95 \mathrm{c}$ \\
\hline & 6 & $0.20 \mathrm{a}$ & $0.53 \mathrm{a}$ & $2.19 \mathrm{a}$ & $4.03 \mathrm{a}$ & $6.73 b$ & $18.55 \mathrm{c}$ \\
\hline $\mathrm{CV}(\%)$ & & \multicolumn{6}{|c|}{9.17} \\
\hline $\mathrm{r}$ & & -0.54 & -0.40 & -0.03 & $-0.89^{* *}$ & $-0.92^{* *}$ & $-0.95^{* *}$ \\
\hline \multirow[t]{6}{*}{25} & 1 & $0.83 \mathrm{a}$ & $2.95 \mathrm{a}$ & $7.88 \mathrm{a}$ & $12.46 \mathrm{a}$ & $21.54 \mathrm{a}$ & $52.31 \mathrm{a}$ \\
\hline & 2 & $0.93 \mathrm{a}$ & $2.76 \mathrm{a}$ & $7.62 \mathrm{a}$ & $12.10 \mathrm{a}$ & $20.17 b$ & $50.66 \mathrm{~b}$ \\
\hline & 3 & $0.79 a$ & $2.59 \mathrm{a}$ & $7.39 \mathrm{a}$ & $11.93 \mathrm{a}$ & $20.15 b$ & $49.28 b$ \\
\hline & 4 & $0.76 \mathrm{a}$ & $2.69 \mathrm{a}$ & $7.06 \mathrm{a}$ & $11.86 \mathrm{a}$ & $19.98 b$ & $50.43 b$ \\
\hline & 5 & $0.88 \mathrm{a}$ & $2.55 \mathrm{a}$ & $7.03 \mathrm{a}$ & $11.77 \mathrm{a}$ & $18.54 \mathrm{c}$ & $48.56 c$ \\
\hline & 6 & $0.48 \mathrm{a}$ & $2.42 \mathrm{a}$ & $6.95 \mathrm{a}$ & $11.48 \mathrm{~b}$ & $18.62 \mathrm{c}$ & $47.77 \mathrm{c}$ \\
\hline $\mathrm{CV}(\%)$ & & \multicolumn{6}{|c|}{6.49} \\
\hline $\mathrm{r}$ & & -0.37 & $-0.91^{* *}$ & $-0.85^{* *}$ & $-0.87^{* *}$ & $-0.95^{* *}$ & $-0.94^{* *}$ \\
\hline \multirow[t]{6}{*}{40} & 1 & $1.34 \mathrm{a}$ & $7.51 \mathrm{a}$ & $20.29 a$ & $35.18 \mathrm{a}$ & $53.54 \mathrm{a}$ & $91.25 \mathrm{a}$ \\
\hline & 2 & $1.43 \mathrm{a}$ & $6.85 \mathrm{a}$ & $20.16 \mathrm{a}$ & $34.93 a$ & $50.04 \mathrm{a}$ & $87.58 \mathrm{~b}$ \\
\hline & 3 & $1.44 \mathrm{a}$ & $7.55 \mathrm{a}$ & $19.93 \mathrm{a}$ & $35.72 \mathrm{a}$ & $52.58 \mathrm{a}$ & $86.21 b$ \\
\hline & 4 & $1.45 \mathrm{a}$ & $6.94 \mathrm{a}$ & $19.37 \mathrm{a}$ & $33.98 \mathrm{a}$ & $49.99 a$ & $84.88 b$ \\
\hline & 5 & $1.32 \mathrm{a}$ & $6.87 \mathrm{a}$ & $19.34 \mathrm{a}$ & $35.12 \mathrm{a}$ & $49.72 \mathrm{a}$ & $85.76 b$ \\
\hline & 6 & $1.12 \mathrm{a}$ & $7.17 \mathrm{a}$ & $20.56 \mathrm{a}$ & $34.41 \mathrm{a}$ & $48.60 \mathrm{a}$ & $83.20 \mathrm{~b}$ \\
\hline $\mathrm{CV}(\%)$ & & \multicolumn{6}{|c|}{26.10} \\
\hline $\mathrm{r}$ & & -0.49 & 0.18 & -0.53 & -0.34 & -0.13 & 0.10 \\
\hline
\end{tabular}

Means followed by the same lowercase letter in the column do not differ statistically from each other at the level of 5\% of error probability by the Scott-Knott test. ** Significant at $5 \%$ of error probability by the test $\mathrm{t}$. 
(reference method), considering that no significant differences $(\mathrm{p}>0.05)$ were detected between the methods by t test (Table 4 ). Also, the correlation analysis showed a simple correlation coefficient of 0.97 ( $\mathrm{p}<0.0001)$ suggesting a linear and directly proportional relationship to that obtained by gas chromatography.

The results obtained for normal seedlings indicated that among the fifteen seed lots, it was possible to form two feasible groups, with germination percentage of 98 and $95 \%$, respectively. The group that presented a higher germination rate resulted in the formation of four groups for the concentration of $\mathrm{CO}_{2}$ released, with averages ranging from 22.39 to $18.46 \mathrm{mmol} \mathrm{g}^{-1} \mathrm{CO}_{2}$, outlining the sensitivity of the method to detect differences in the physiological potential in seeds with similar germination. It is also observed the tendency of reduction in the release of $\mathrm{CO}_{2}$ as the germinative rate increased, considering that the inverse relation between the tests resulted in a correlation coefficient of -0.93 ( $\mathrm{p}<0.0001)$.

Aditionaly, the methodology proposed in the present study can be widely used in the quality control of seed production, processing, and storage in wheat seed
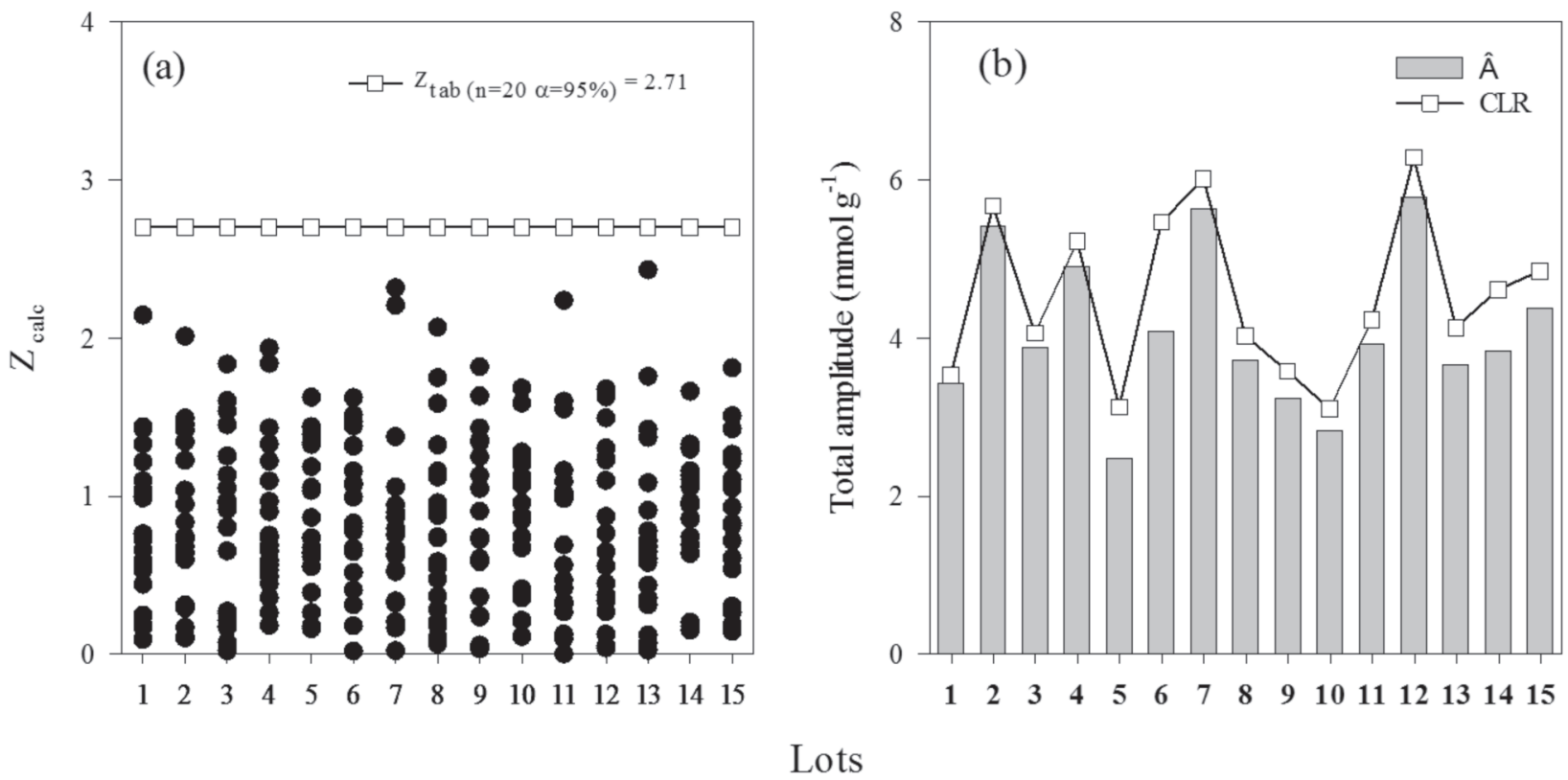

Figure 2: (a) Extreme value test (Grubbs' test) applied to the results of the $\mathrm{CO}_{2}$ concentration in fifteen seed lots of Triticum aestevium CD 123. (b) Precision analysis by comparing critical limit of repeatability (CLR) with total amplitude ( $\hat{A})$.

Table 3: Repeatability evaluation by comparing days of analysis per lots of Triticum aestevium CD 123 seeds.

\begin{tabular}{|c|c|c|c|c|c|}
\hline \multirow{2}{*}{ Lot } & \multirow{2}{*}{$\begin{array}{l}\text { First day } \\
(\mathrm{n}=10) \\
\text { mmol g }^{-1}\end{array}$} & \multirow{2}{*}{$\begin{array}{c}\begin{array}{c}\text { Second day } \\
(n=10)\end{array} \\
Q_{\text {Mdia }}\end{array}$} & \multicolumn{3}{|c|}{ ANOVA } \\
\hline & & & $\mathbf{F}_{\text {calc }}$ & & $\mathbf{P}$ \\
\hline 1 & $24.95 \pm 1.22$ & $24.74 \pm 0.72$ & 0.229 & 0.227 & 0.639 \\
\hline 2 & $23.71 \pm 1.64$ & $25.10 \pm 1.23$ & 9.638 & 3.113 & 0.065 \\
\hline 3 & $23.71 \pm 1.09$ & $23.99 \pm 1.21$ & 0.406 & 0.306 & 0.587 \\
\hline 4 & $23.75 \pm 1.57$ & $24.00 \pm 1.40$ & 0.306 & 0.138 & 0.714 \\
\hline 5 & $23.43 \pm 0.74$ & $23.91 \pm 0.96$ & 1.142 & 1.549 & 0.229 \\
\hline 6 & $23.37 \pm 1.22$ & $23.87 \pm 1.61$ & 1.218 & 0.600 & 0.449 \\
\hline 7 & $22.31 \pm 1.50$ & $22.82 \pm 1.88$ & 1.287 & 0.445 & 0.513 \\
\hline 8 & $22.59 \pm 1.09$ & $22.53 \pm 1.20$ & 0.021 & 0.016 & 0.902 \\
\hline 9 & $21.98 \pm 0.94$ & $21.64 \pm 1.07$ & 0.584 & 0.577 & 0.457 \\
\hline 10 & $21.04 \pm 0.93$ & $21.21 \pm 0.84$ & 0.149 & 0.191 & 0.668 \\
\hline 11 & $20.86 \pm 1.21$ & $21.32 \pm 1.16$ & 1.043 & 0.741 & 0.401 \\
\hline 12 & $20.29 \pm 1.91$ & $21.29 \pm 1.50$ & 4.980 & 1.686 & 0.211 \\
\hline 13 & $20.19 \pm 1.24$ & $20.25 \pm 1.12$ & 0.019 & 0.014 & 0.908 \\
\hline 14 & $19.42 \pm 1.15$ & $20.13 \pm 1.37$ & 2.557 & 1.600 & 0.222 \\
\hline 15 & $17.97 \pm 1.41$ & $18.94 \pm 1.16$ & 4.691 & 2.821 & 0.110 \\
\hline
\end{tabular}


Table 4: Accuracy analysis by comparison of the $\mathrm{CO}_{2}$ concentration by the reference method with the proposed method, by simple correlation (R) and comparison of means of the proposed method and percentage of normal seedlings (PN) of 15 lots of Triticum aestevium $\mathrm{CD} 123$.

\begin{tabular}{|c|c|c|c|c|}
\hline \multirow[t]{2}{*}{ Lot } & $\begin{array}{l}\text { Reference method } \\
\qquad(n=4)\end{array}$ & $\begin{array}{l}\text { Proposed method } \\
\qquad(\mathbf{n}=\mathbf{2 0})\end{array}$ & PN & \multirow[t]{2}{*}{$\rho_{\text {test t }}$} \\
\hline & \multicolumn{2}{|c|}{$\mathrm{mmol} \mathrm{g}^{-1}$} & $\%$ & \\
\hline 1 & $25.69 \pm 1.73$ & $24.84 \pm 0.98 \mathrm{a}$ & $94 \mathrm{~b}$ & 0.18 \\
\hline 2 & $24.77 \pm 2.70$ & $24.40 \pm 1.58 \mathrm{a}$ & $95 \mathrm{~b}$ & 0.71 \\
\hline 3 & $23.32 \pm 1.48$ & $23.85 \pm 1.13 b$ & $96 \mathrm{~b}$ & 0.46 \\
\hline 4 & $22.96 \pm 1.71$ & $23.78 \pm 1.45 b$ & $95 \mathrm{~b}$ & 0.45 \\
\hline 5 & $23.72 \pm 0.49$ & $23.63 \pm 0.81 b$ & $96 \mathrm{~b}$ & 0.83 \\
\hline 6 & $23.43 \pm 2.39$ & $23.62 \pm 1.41 \mathrm{~b}$ & $96 \mathrm{~b}$ & 0.36 \\
\hline 7 & $21.94 \pm 2.51$ & $22.39 \pm 1.49 c$ & $97 \mathrm{a}$ & 0.63 \\
\hline 8 & $22.55 \pm 2.26$ & $22.35 \pm 1.21 \mathrm{c}$ & $98 \mathrm{a}$ & 0.80 \\
\hline 9 & $21.31 \pm 0.70$ & $21.81 \pm 1.00 \mathrm{~d}$ & $98 \mathrm{a}$ & 0.36 \\
\hline 10 & $20.79 \pm 1.26$ & $21.13 \pm 0.86 \mathrm{~d}$ & $98 \mathrm{a}$ & 0.51 \\
\hline 11 & $20.55 \pm 0.97$ & $20.94 \pm 1.18 \mathrm{~d}$ & $98 \mathrm{a}$ & 0.40 \\
\hline 12 & $21.45 \pm 0.24$ & $20.68 \pm 1.75 \mathrm{~d}$ & $99 \mathrm{a}$ & 0.46 \\
\hline 13 & $19.87 \pm 1.71$ & $20.12 \pm 1.15 \mathrm{e}$ & $99 \mathrm{a}$ & 0.60 \\
\hline 14 & $18.42 \pm 0.70$ & $19.59 \pm 1.29 \mathrm{e}$ & $99 \mathrm{a}$ & 0.59 \\
\hline 15 & $19.13 \pm 0.45$ & $18.46 \pm 1.35 \mathrm{f}$ & $99 a$ & 0.34 \\
\hline
\end{tabular}

Where: $p_{\text {test }}$ and $p=$ probability of significance by the two-tailed $t$ test. Means followed by the same lowercase letter in the column do not differ statistically from each other at the level of $5 \%$ of error probability by the Scott-Knott test.

industries, as well as in quantifying the respiratory activity of biological organisms that result in the release of $\mathrm{CO}_{2}$ by oxidative and fermentative processes.

\section{CONCLUSIONS}

For the evaluation of the respiratory activity in Triticum aestevium seeds using $\mathrm{CO}_{2}$ concentration, it is recommended to incubate the samples at $25^{\circ} \mathrm{C}$ for a minimum period of 12 hours, which allows to classify lots with different levels of vigor and to predict the establishment of seedlings in the field. Based on the intra-laboratory validation, this methodology is adequate for the measurement of $\mathrm{CO}_{2}$ in seeds, since externalize precision between successive measurements and agreement with the reference method.

\section{REFERENCES}

Bandeira JM, Marini P, Martins ABN, Borba ICG, Amarante L \& Moraes DM (2013) Relationships between the physiological and biochemical modifications in soybean seeds under different temperatures. African Journal of Agricultural Research, 8:53695375 .

Benamar A, Tallon C \& Macherel D (2003) Membrane integrity and oxidative properties of mitochondria isolated from imbibing pea seeds after priming or accelerated ageing. Seed Science Research, 13:35-45.

Brasil (2013) Instrução Normativa no 45, de 17 de setembro de 2013. Regulamento técnico geral dos padrões para a produção e a comercialização de sementes de grandes culturas. DOU, 18/ 09/2013, Seção 1, p. 16-37.
Brasil (2009) Regras para análise de sementes. Brasília, Mapa/ ACS. 395p.

Chui QSH, Barros CB \& Silva TD (2009) Parâmetros r e R obtidos de programa interlaboratorial - como usá-los. Química Nova, 32:2209-2213.

Dantas BF, Silva RCB, Ribeiro RC \& Aragão CA (2015) Respiration and antioxidant enzymes activity in watermelon seeds and seedlings subjected to salt and temperature stresses. American Journal of Experimental Agriculture, 7:70-77.

Dranski JAL, Pinto Júnior AS, Herzog NFM, Malavasi UC, Malavasi MM \& Guimarães VF (2013) Vigor of canola seeds through quantification of $\mathrm{CO}_{2}$ emission. Ciência e Agrotecnologia, 37:229-236.

Favarato LF, Rocha VS, Espíndula MC, Souza MA \& Paula GS (2011) Teste de lixiviação de potássio para avaliação da qualidade em sementes de trigo. Revista Brasileira de Ciências Agrárias, 6:670-674.

Felinger A (1998) Data analysis and signal processing in chromatography. Oxford, Elsevier. 414p.

ISO - International Standard Organization (1994) Accuracy (trueness and precision) of measurement methods and results. Part 2. Basic method for the determination of repeatability and reproducibility of a standard measurement method (ISO 5725$2: 1994)$. Geneva, International Organization for Standardization. 42 p.

ISTA - International Seed Testing Association (1995) Handbook of vigor tests methods. $3^{\mathrm{a}}$ ed. Zürich, ISTA. $117 \mathrm{p}$.

Kataoka VY, Carvalho MLM, Oliveira MS \& Caldeira CM (2011) Validação de metodologia para o teste de germinação em sementes de nabo forrageiro (Raphanus sativus L. var. oleiferus). Revista Brasileira de Sementes, 33:69-79. 
Loeffler TM, Tekrony DM \& Egli DB (1988) The bulk conductivity test as an indicator of soybean seed quality. Journal of Seed Technology, 12:37-53.

Mapa (2016) A cultura do trigo - 2016. Disponível em: <http:// www.agricultura.gov.br/vegetal/culturas/trigo>. Acessado em: 11 de fevereiro de 2016.

Marcos Filho J (2015) Seed vigor testing: an overview of the past present and future perspective. Scientia Agricola, 72:363-374.

Mendes CR, Moraes DM, Lima MGS \& Lopes NF (2009) Respiratory activity for the differentiation of vigor on soybean seeds lots. Revista Brasileira de Sementes, 31:171-176.

Menezes VO, Lopes SJ, Tedesco SB, Henning FA, Zen HD \& Mertz LM (2014) Cytogenetic analysis of wheat seeds submitted to artificial aging stress. Journal of Seed Science, 36:71-78.

Nakagawa J (1994) Testes de vigor baseados na avaliação das plântulas. In: Vieira RD \& Carvalho NM (Eds.) Testes de vigor em sementes. Jaboticabal, FUNEP. p.49-85.
Patanè C \& Avola G (2013) A seed respiration-based index of coldsensitivity during imbibition in four macrothermal species. Acta Physiologiae Plantarum, 35:911-918.

Rosental L, Nonogaki K \& Fait A (2014) Activation and regulation of primary metabolism during seed germination. Seed Science Research, 24:01-15.

Schabes FI \& Sigstad EE (2011) Monitoring soybean seed germination by calorimetry. Journal of Thermal Analysis and Calorimetry, 104:05-11.

Shaban M (2013) Review on physiological aspects of seed deterioration. International Journal of Agricultural and Crop Sciences, 6: 627-631.

Weitbrecht K, Müller K \& Leubner-Metzger G (2011) First off the mark: early seed germination. Journal of Experimental Botany, 62:3289-3309. 